Article

\title{
The Dynamics of Beech Roundwood Prices in Selected Central European Markets
}

\author{
Anna Kożuch * and Jan Banaś (i) \\ Department of Forest Resources Management, Faculty of Forestry, University of Agriculture in Krakow, \\ al. 29-listopada 46, 31-425 Krakow, Poland; jan.banas@urk.edu.pl \\ * Correspondence: a.janusz@ur.krakow.pl
}

Received: 19 July 2020; Accepted: 17 August 2020; Published: 19 August 2020

check for updates

\begin{abstract}
The European beech (Fagus sylvatica L.) is the most prevalent deciduous tree species in Central Europe. The implementation of sustainable, close-to-nature silvicultural practices increased the percentage share of beech in forest species composition, raising the economic significance of beech roundwood, especially in terms of revenues from timber sales. The elucidation of roundwood price mechanisms as well as long-term equilibrium relations between international markets may be helpful in calculating the profitability of beech roundwood production. The study material consists of quarterly time series of beech roundwood prices from Austria, Czechia, Germany, Poland, Slovakia, and Slovenia in the years 2005-2018. The price time series were described with a multiplicative model incorporating seasonal, cyclical, and irregular, as well as long-term trend components. The time series were decomposed using the Census X11 method. Stationarity was tested by means of the augmented Dickey-Fuller test (ADF) and the Kwiatkowski-Phillips-Schmidt-Shin test (KPSS). Cointegration was assessed using the Johansen and Engle-Granger methods. From 2005-2018, the highest mean beech roundwood prices were found for Austria $\left(77.5 € \mathrm{~m}^{-3}\right)$ and Germany, and the lowest for Poland and Slovakia. Roundwood prices were badly affected by the 2008/2009 financial crisis, which caused an approx. $27 \%$ decline. The prices of large-diameter beech logs exhibited seasonal fluctuations, typically reaching a maximum in Q1 and a minimum in Q3. The amplitude of those fluctuations was the highest in Slovenia in 2005 (10.1\%), while in Czechia and Germany, seasonal effects increased over the period of study. The lowest seasonality was found in Slovakia and Austria (in the latter country it was not statistically significant). On an annual scale, cyclical changes generally accounted for the largest proportion of price variation, and were particularly pronounced in Poland $(78.9 \%)$, Slovakia (78.6\%), and Austria (69.2\%). On the other hand, seasonal effects were predominant in the Slovenian (40.6\%), German (34.1\%), and Czech (33.3\%) markets. In countries with price series of type $I(0)$, simple correlation between stationary beech roundwood prices is positive and the strongest between Czechia-Poland and Czechia-Austria; on the other hand they are the weakest in the German market. In Slovakia and Slovenia with nonstationary price series, both Johansen's and Engle-Granger's cointegration tests indicated the absence of a long-term equilibrium between the analyzed beech timber markets. Results revealed integration between the prices of large-diameter beech logs in Czechia, Austria, and Poland. It should be mentioned that in this study, the time series of price used are rather short for long time cointegration analysis, which might prevent the proper detection of cointegration between all analyzed countries.
\end{abstract}

Keywords: timber market; timber price; beech roundwood; price fluctuations; market cointegration; time series 


\section{Introduction}

The implementation of multifunctional forestry leads to a situation where silviculture is expected to pursue several contradictory objectives. The focus on social and conservation functions altered management practices, limiting forest availability for timber supply [1-3]. The most important criterion affecting the decisions of forest managers is invariably revenue from timber sales [4,5], which depends, among other aspects, on the species composition and quality of stands [6]. In line with close-to-nature, sustainable silviculture, the proportion of mixed stands has been on the rise over the years, while the growing stocks of softwood in Europe have been on the decline [7,8]. From an economic standpoint, mixed forests are deemed less profitable for investors [9,10]. Knoke et al. [11] pointed to the need to integrate the findings on biophysical properties of mixed forests such as growth, yield, and ecological stability against natural hazards into forest economic model-making. Mixed forests reduce the profitability but also show diversification effects and diversified time structure of the timber harvests. Multi-criteria forest management does not generally require high proportions of broadleaved tree species [12]. Risk-averse decision-makers should therefore establish ecologically desired mixed forests with beech proportions between $10 \%$ and $50 \%$, even if the profitability for mixed forests decreases [13]. They will however benefit largely due to a significant risk attenuation $[14,15]$.

Given the increasing area and stocks of beech stands, the revenues of forest owners will be largely determined by the demand for beech logs generated by the wood industry (lower quality assortments will be absorbed by the energetic sector).

In Poland, a 1\% increment in the area of beech forests growing on mixed coniferous sites results in an overall timber production decrease by $1.40-1.85 \%$ [16]. The mean price per cubic meter of softwood and oak wood harvested throughout the stand development cycle is higher than that of beech roundwood by $20-30 \%$ and $90-100 \%$, respectively.

In forest management planning, the main sources of uncertainty are financial results, variability and fluctuations in timber prices, as well as environmental factors (e.g., natural disasters induced by climate change) [4]. Timber prices are important for forest management optimization, and so analysis of historical price series is an important tool supporting investment and harvest decisions with a view to maximizing benefits from price fluctuations [17-19]. The mechanisms underpinning timber markets and prices have been previously explored by $[17,20-25]$, who focused on trends and the underlying causes of price variability.

Price time series are the basis for analyzing the dynamics of market phenomena and may also be used for forecasting $[13,26]$. Time series can be decomposed to identify long-term trends, as well as periodic components which reflect regular deviations from the trend. The periodic component may be manifested as cyclical fluctuations (long-run periodic changes such as economic cycles) or as seasonal fluctuations on an annual scale attributable to the effects of seasonal patterns of activity consisting of several phases. Analysis of timber price variability may reveal characteristic patterns of change over time, which can be used to predict timber prices as well as evaluate the current situation in the market; such information can also be used for the purpose of shaping future price levels [27].

The globalization of the forest industry has given rise to interconnections between markets and the need to quickly react to macroeconomic changes [28,29]. Therefore, increasing attention has been devoted to analysis of current market conditions and short-term forecasting, which play an essential role in managing forest resources, with prices being crucial predictors [24,30-33]. Relatively little is known about the stochastic properties of roundwood prices, relationships between different timber markets, and in particular the ways in which they affect market policies and economic changes. The elucidation of price relationships between local timber markets is critical in the context of forecasting future roundwood prices. The degree of integration of geographic markets can be best understood by investigating the intercorrelations of market prices rather than trade flows. This is because prices reflect market development, being determinants of both demand and supply, and are also the best predictors of future changes [28]. Relationships between market prices are a major research area addressed by several studies over the years [18,34-40], many of which have applied cointegration 
analysis to eliminate the problem of spurious regression (it arises from the fact that when variables are non-stationary, the distribution of the $t$-statistic is not a $t$-distribution). Variables are cointegrated if there exists a linear combination of them that is stationary. The notion of cointegration may be likened to the concept of long-term equilibrium based on Granger's theorem, which enables an interpretation of the cointegrating vector as a long-term relationship between variables. The Engle-Granger method can be applied if all variables exhibit first-order integration $I(1)$, and then cointegration is evaluated by testing stationarity using ADF. Markets are deemed to be integrated when they exhibit similar prices, irrespective of the buyers and sellers of a given product. It may be expected that with the advancing globalization of timber production roundwood prices in different countries may follow increasingly similar patterns [41].

The volume of beech roundwood produced in Central Europe is likely to increase, and so analysis of historical data for the primary timber market, including price time series decomposition, can make a difference for forest managers and owners in terms of harvest planning, as well as for investors in terms of purchasing or selling forests [42-45]. In addition, an understanding of linkages between selected international markets (horizontal cointegration) will enable enterprises in the wood industry to optimize their business decisions, and suppliers to correctly evaluate the situation in the domestic and foreign markets [46].

The objective of the study was to analyze large-diameter beech log prices in the primary timber markets of selected Central European countries in the years 2005-2018; in particular (1) price changes were analyzed using time series decomposition into long-term trends as well as cyclical, seasonal, and irregular components, and (2) long-term relationships between selected Central European markets were examined in terms of beech roundwood prices.

\section{Beech Growing Stock and Roundwood Trade in Europe}

The European beech is the most prevalent deciduous tree species in Central Europe [47]. In Croatia, Romania, and Slovenia it is economically the most important tree species, representing 36\%, 31.5\%, and $31 \%$ of the tree species composition, respectively. Also in Slovakia it is of great economic significance, accounting for $30 \%$ of forest area. In Germany it constitutes $15 \%$ of the tree species composition, being the most widespread hardwood tree. In Austria, Czechia, and Poland, the percentage share of that tree species is much lower $(10 \%, 7 \%$, and $5.5 \%$, respectively). In 2000 , the growing stock of beech in Germany amounted to 583 million $\mathrm{m}^{-3}\left(352 \mathrm{~m}^{-3} / \mathrm{ha}\right)$; it has now increased to more than 635 million $\mathrm{m}^{-3}$. The beech stocks amount to more than 166 million $\mathrm{m}^{-3}$ in Poland, 139 million $\mathrm{m}^{-3}$ in Slovakia, 105 million $\mathrm{m}^{-3}$ in Slovenia, 100 million $\mathrm{m}^{-3}$ in Austria, and 41 million $\mathrm{m}^{-3}$ in Czechia.

The area and growing stock of beech forests in central Europe have been on the increase in recent years. Long-term studies conducted in Brno have revealed an expansion in beech stand volume [48,49]. Also reports from Slovakia, Austria, and Poland have indicated quantitative and volume increments for the European beech, as well as high regeneration levels in beech stands [50,51]. Taking into account climate change, which affects forest stability and productivity [52] and the revenues of forest owners [53], it should be noted that higher temperatures and lower precipitation levels will favor further beech expansion in central Europe, probably extending its horizontal and altitudinal ranges [54,55]. On the other hand, according to some climate scenarios, in southern Europe and in the southern region of Central Europe, beech growth is likely to slow down with some beech stands dying back due to their susceptibility to droughts at the beginning of the vegetative season [56-59].

In the years 2001-2018, the total exports and imports of beech roundwood in Europe remained at similar levels, amounting to 56.8 million $\mathrm{m}^{3}$ and 54.0 million $\mathrm{m}^{3}$, respectively. Beech roundwood was exported mainly from Germany-665.1 thousand $\mathrm{m}^{3}$ year $^{-1}$, as well as France and Slovakia approx. 444 thousand $\mathrm{m}^{3}$ year $^{-1}(14 \%)$. At the same time, the greatest volumes of beech roundwood were imported by Austria-892.7 thousand $\mathrm{m}^{3}$ year ${ }^{-1}$, Italy (572.9 thousand $\mathrm{m}^{3}$ year $^{-1}$ ), and Belgium (475 thousand $\mathrm{m}^{3}$ year $^{-1}$ ) (Figure 1). On the global market of beech sawnwood, Romania (27.9\%), 
Germany $(17.8 \%)$ and Croatia (16.9\%) exported the most. Imports were dominated by Italy (126.7 thousand $\mathrm{m}^{3}$ year $^{-1}$ ).

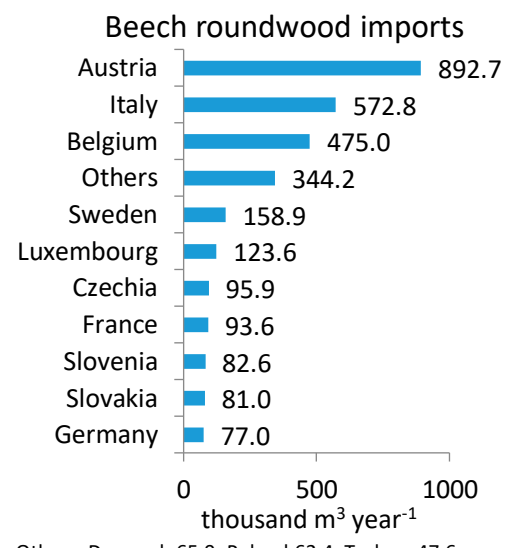

Others: Denmark 65.0; Poland 62.4; Turkey; 47.6 Hungary 45.2; Switzerland 43.8; Spain 25.0; Canada 23.7; Romania 11.3; Croatia 5.5;

Portugal 5.4; Bosnia i Herzegovina 4.2;

Serbia 2.9; Netherlands 1.3;

Latvia 0.9 (thousand $\mathrm{m}^{3}$ year $^{-1}$ )

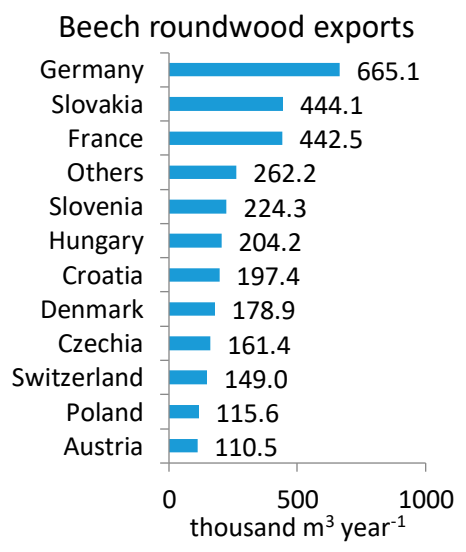

Others: Ukraine 74.0; Bulgaria 60.1; Belgium 48.7; Romania 34.5; Serbia 10.4; Spain 9.0; Russian Federation 7.2; Luxemburg 6.0; Netherlands 5.6 ; Italy 5.5 ;

Albania 1.4 (thousand $\mathrm{m}^{3}$ year ${ }^{-1}$ )

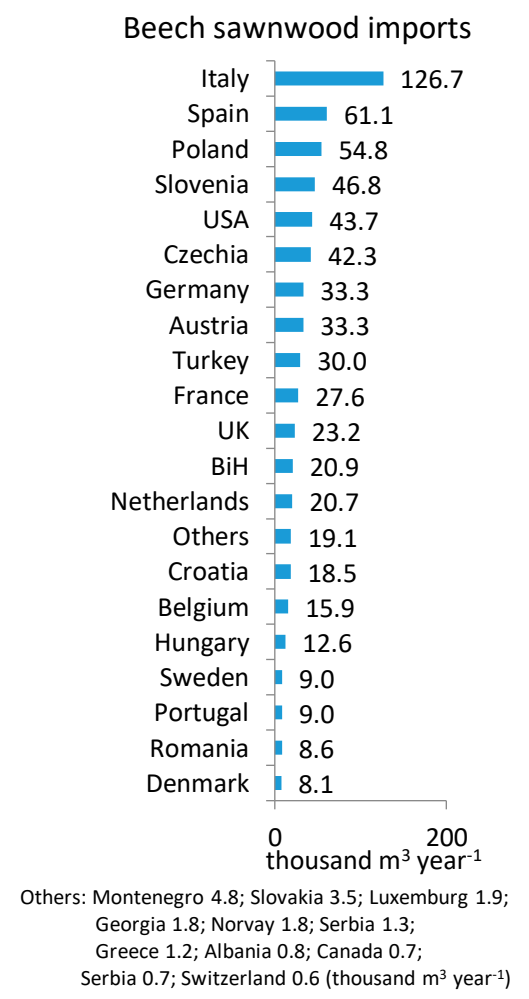

\section{Beech sawnwood exports}

\begin{aligned} Romania & \multicolumn{1}{c}{575.4} \\ Germany & 367.6 \\ Croatia & 349.6 \\ Others & 161.0 \\ France & 155.7 \\ BiH & 118.6 \\ Slovakia & 70.7 \\ Serbia & 64.2 \\ Austria & 58.3 \\ Slovenia & 52.7 \\ Poland & 39.7 \\ SUSM & 27.5 \\ Bulgaria & 24.3 \\ & 0 \\ & 0 \\ & thousand $\mathrm{m}^{3}$ year $^{-1}\end{aligned}$

Others: Italy 18.1; Switzerland 17.0; Czechia 16.5; Ukraine 16.4; North Macedonia 1.3; Russian
Federation 12.5; Belgium 11.9; Georgia 11.2 Denmark 11.2; Albania 9.1; USA 7.5; Montenegro 5.9; Hungary 5.8; Spain 2.4; Turkey 2.2 (thousand $\mathrm{m}^{3}$ year ${ }^{-1}$ )

Figure 1. Volume of beech roundwood and sawnwood exports and imports by country in the years 2001-2018.

In the years 2013-2017 the output of the wood industry in Central European countries varied, with Germany characterized by stable production levels and the highest growth rates recorded for Slovakia (38.5\%), Slovenia (25.6\%), and Poland (22.3\%) [60]. It should be noted that in 2013-2017 France and Germany were the largest exporters, jointly responsible for $44 \%$ of hardwood log exports. A substantial portion of those exports went to Asia, with $23 \%$ of beech roundwood being shipped 
to China, which is the largest timber importer in the world, accounting for as much as $32 \%$ of total industrial roundwood imports. In 2014, Chinese imports of hardwood (logs and sawn) reached 29.8 million $\mathrm{m}^{3}$ (USD 10.6 billion), while their imports of hardwood sawtimber amounted to USD 4.3 billion. After the 2015 imposition of a commercial logging ban in all Chinese natural forests, China's sawn hardwood imports increased by 16.38\% (in volume) in 2016 and 10.61\% in 2017 [61]. Germany and Austria are the second and third largest roundwood importers in the world, respectively. In 2003, exports of beech logs to China from European countries amounted to 300 thousand. $\mathrm{m}^{-3}$ (including 270 thousand. $\mathrm{m}^{-3}$ from Germany). Export prices of German beechwood to China without freight costs in 2004 was $226 € \mathrm{~m}^{-3}$ for beech lumber and $52 € \mathrm{~m}^{-3}$ beech logs.

In the years 2001-2007, beech roundwood exports declined from 4 million $\mathrm{m}^{3}$ to 2.2 million $\mathrm{m}^{3}$, but then increased during the period of economic slowdown. Roundwood exports from Europe reached maximum values in 2001 and 2014 (approx. 4 million $\mathrm{m}^{3}$ ). The prices of exported roundwood were the highest at the height of global economic prosperity in $2007\left(103.86 \mathrm{USD} / \mathrm{m}^{3}\right)$ and in 2018 (100 USD/m , see Figure 2).

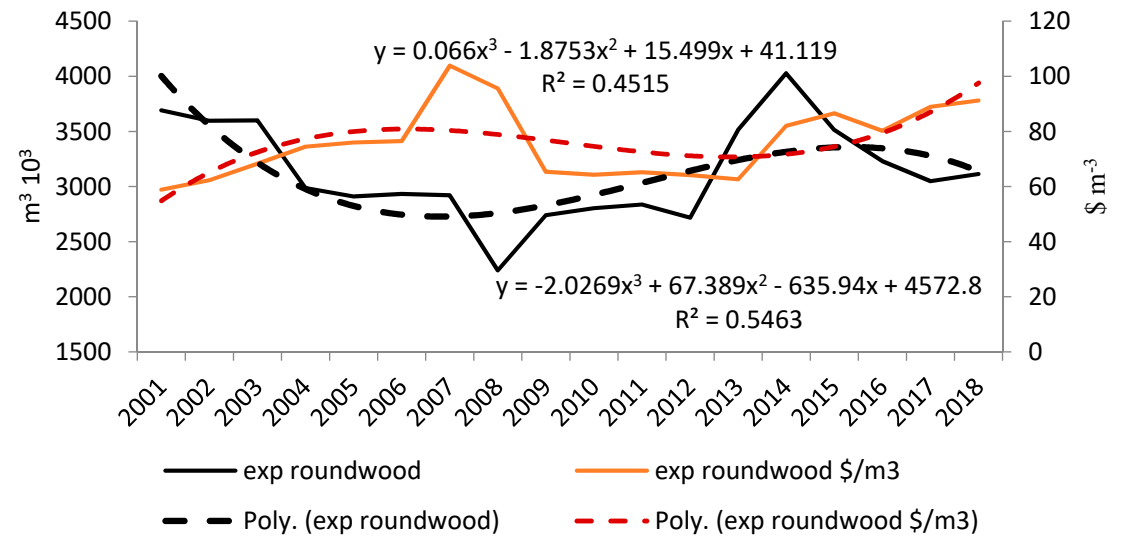

Figure 2. Volume (left axis) and prices (right axis) of beech roundwood exports in the years 2001-2018.

Since 2001, there has been an upward trend in the volume of roundwood imported by European countries, with the imports doubling within the study period (Figure 3). The prices of imported large-diameter beech logs peaked in 2007 at $114 \mathrm{USD} / \mathrm{m}^{3}$, while in the years 2008-2018 they declined to $62 \mathrm{USD} / \mathrm{m}^{3}$.

In 2018, the European production of sawn hardwood remained below the 2006-2007 maximum, which had been reached just before the outbreak of the global economic crisis. The sawn hardwood markets are linked to the furniture and woodworking industries, which have been on an increase in the years 2013-2017 in Central and Eastern Europe, but not in Western Europe, where Belgium, Germany, and France have experienced a stagnation, with a small decline in 2018 [62,63].

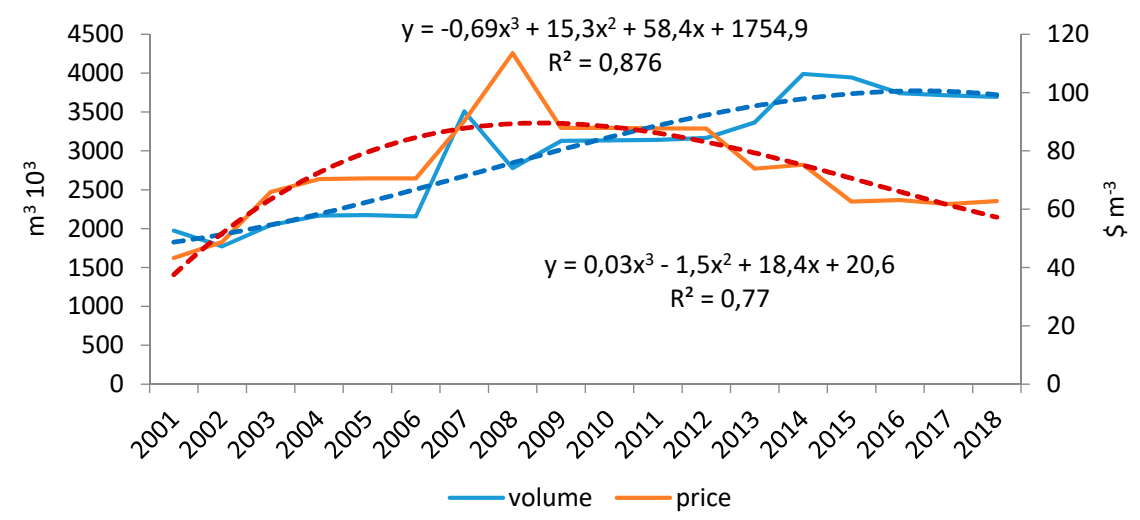

Figure 3. Volume (left axis) and prices (right axis) of beech roundwood imports in the years 2001-2018. 


\section{Materials and Methods}

\subsection{Materials}

The study material consisted of quarterly time series of nominal beech roundwood prices in the years 2005-2018. Data for Austria, Czechia, Germany, and Slovenia were taken from the FAO Database [64], those for Slovakia from the Forestry Market Information System-Forest Portal [65], and those for Poland from reports of the State Forest Information System (SILP). Prices for all countries were given as mean quarterly prices in $€ \mathrm{~m}^{-3}$ according to the following procedure. In the FAO Database, monthly time series for Germany, Austria, and Slovenia were converted into quarterly series by adopting prices from the middle month for a given quarter (February for Q1, May for Q2, August for Q3, and November for Q4). In addition, German prices were converted from relative values (the FAO Database provides only a percentage price index [\%] for that country) into Euros, adopting a mean 2010. In the case of prices originally given in other currencies, they were converted into Euros using quarterly exchange rates published by the Czech National Bank for Czechia [66] and by the National Bank of Poland for the Polish zloty [67].

Price comparisons between countries are difficult due to different timber classifications as well as trade parities $[68,69]$. Thus, the present analysis included nominal prices of large-diameter roundwood since quality requirements for logs are very similar across countries, and so comparisons are likely to provide reliable information. Analysis included mean prices of large-diameter beech logs, net of value added tax, and whether timber was sold at the roadside or landing near the harvest site.

\subsection{Price Time Series Decomposition}

Roundwood price time series were described using a multiplicative model incorporating four components of the following form [70]:

$$
Y_{t}=T_{t} \cdot C_{t} \cdot S_{t} \cdot I_{t}
$$

where: $Y_{t}$-roundwood price in period $t, T_{t}$-long-term trend, $C_{t}$-cyclical component, $S_{t}$ - seasonal component, $I_{t}$-irregular component.

Individual components of the time series were identified using the Census X11 method (Statistica 13.1 package). Seasonality was eliminated from the initial series by dividing empirical price values by the corresponding seasonality indicators. The trend-cycle (TC) component was extracted from the time series as a Henderson moving average, and then it was decomposed into a long-term trend $(T)$ and cyclical fluctuations $(C)$ by means of the Hodrick-Prescott filter. In turn, irregular changes (I) were extracted by dividing the time series without the seasonal component by the trend-cycle. The significance of seasonal fluctuations was estimated using the $F$ test. To determine the relative contributions of the various components to the overall price variation, the proportions of the variance of those components in the total variance was calculated for time horizons of one to four quarters. Annual means were also computed.

\subsection{Cointegration of Beech Roundwood Markets}

To elucidate price dynamics between the analyzed markets, it was essential to examine the properties of price time series in the studied countries. For countries with stationary price series simple regression was performed. However, the application of linear regression may lead to spurious results if the price time series involved are non-stationary.

Cointegration between markets can be evaluated when the price time series are non-stationary, while their first differences are stationary, i.e., when time series exhibit first-order integration I(1). Non-stationarity was estimated using the augmented Dickey-Fuller test (ADF) [71] and the Kwiatkowski-Phillips-Schmidt-Shin test (KPSS) [72]. In ADF, the null hypothesis is that the process is non-stationary and can be rejected if evidence against it is sufficiently strong, so this test conservatively 
supports non-stationarity. On the other hand, in KPSS the null hypothesis is that the series is stationary, and so it conservatively supports stationarity. After determining the order of process integration, price time series with $I(1)$ were tested for the presence of a long-term equilibrium reflected by cointegration between those series. Cointegration was tested using Johansen's method [73,74] in conjunction with Engle-Granger's two-step procedure [75]. For the purpose of implementing Johansen's method, the basic VAR form:

$$
X_{t}=\sum_{i=1}^{k} A_{i} X_{t-i}+e_{t}
$$

was transformed into an incremental form:

$$
\Delta X_{t}=\sum_{i=1}^{k-1} \Gamma_{i} \Delta X_{t-1}+\Pi X_{t-1}+e_{t}
$$

where: $\Delta X_{t}$-first increments of the studied variables (prices in individual countries), $\Gamma_{i}=-I+A_{1}+A_{2}$ $+\ldots+A_{I}(I$ - unit matrix $), \Pi_{i}=-I+A_{1}+A_{2}+\ldots+A_{I}, A_{I}$-matrix of model parameters, $\varepsilon_{t}$ - vector of random components.

In the Johansen method, matrix $\Pi$ is an unspecified matrix, while in the alternative method matrix $\Pi=\alpha \beta, \alpha \beta$ is an unknown cointegrating matrix. If the rank $r$ of the cointegrating matrix $\beta$ is lesser than the number of variables in the model $(n)$, then the first $r$ eigenvectors are cointegrating vectors. Johansen's method is based on the trace statistic and the maximum eigenvalue. The null hypothesis in the trace test is that there are no cointegrating vectors, with the alternative hypothesis being that there is at least one such vector. On the other hand, the statistic based on the maximum eigenvalue of the matrix tests the null hypothesis that there is no cointegrating vector, with the alternative hypothesis being that there is one such vector.

Cointegration testing by the Engle-Granger method was conducted in the following steps:

1. Each series was tested for a unit root using ADF.

2. Cointegrating regression was run via OLS. To this end, a potentially cointegrated dependent variable ( $y_{t}$-beech roundwood price in one country) and another potentially cointegrated variable $\left(x_{t}\right.$-beech roundwood price in another country) were selected as regressors.

$$
y_{t}=\gamma_{0}+\gamma_{1} x_{t}+\varepsilon_{t}
$$

3. ADF was performed on residuals $\left(\varepsilon_{t}\right)$ from the cointegrating regression.

The idea is that cointegration is supported if (a) the null hypothesis of non-stationarity is not rejected for each of the series individually in step 1 , while (b) the null hypothesis of non-stationarity is rejected for the residuals at step 3, i.e., each individual series exhibits $I(1)$ but some linear combination of the series reveals $I(0)$. Market cointegration was tested using the Gretl 2020b package [76].

\section{Results}

\subsection{Price Level and Variability}

Nominal prices of beech roundwood differed considerably between the analyzed countries (Figure 4). In the years 2005-2018, the highest mean price of large-diameter beech logs recorded in Austria $\left(77.5 € \mathrm{~m}^{-3}\right)$, with prices in Poland being $40 \%$ lower $\left(47.2 € \mathrm{~m}^{-3}\right.$, see Table 1$)$. Also the maximum price in the Central European market was found in Austria $\left(83 € \mathrm{~m}^{-3}\right)$, which was higher by $25 € \mathrm{~m}^{-3}$ relative to Poland. The minimum price in Austria exceeded the maximum prices in Poland, Slovakia, and Slovenia. The lowest prices were found in the Polish $\left(34.2 \mathrm{~m}^{-3}\right)$ and Slovak $39.0\left(\mathrm{~m}^{-3}\right)$ markets. 


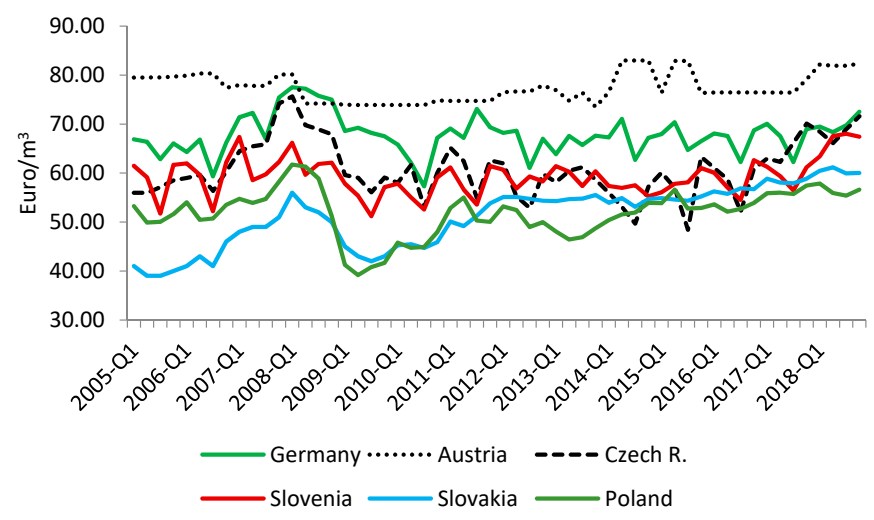

Figure 4. Nominal prices of beech roundwood in selected European countries in 2005-2018.

Table 1. Descriptive statistics for quarterly time series of beech roundwood prices in selected European markets.

\begin{tabular}{cccccccc}
\hline & Unit & Austria & Czechia & Germany & Slovenia & Slovakia & Poland \\
\hline Mean & $€ \mathrm{~m}^{-3}$ & 77.5 & 60.9 & 67.8 & 59.4 & 51.3 & 51.9 \\
Median & $€ \mathrm{~m}^{-3}$ & 76.5 & 60.1 & 67.6 & 59.3 & 53.9 & 52.7 \\
Maximum & $€ \mathrm{~m}^{-3}$ & 83.0 & 75.7 & 77.5 & 68.0 & 61.2 & 61.8 \\
Minimum & $€ \mathrm{~m}^{-3}$ & 73.5 & 48.4 & 57.3 & 51.2 & 39.0 & 39.2 \\
Max/min & - & 1.1 & 1.6 & 1.4 & 1.3 & 1.6 & 1.6 \\
Standard deviation & - & 3.0 & 5.8 & 4.1 & 3.8 & 6.2 & 4.8 \\
Variability coefficient & $\%$ & 3.8 & 9.6 & 6.0 & 6.5 & 12.2 & 9.3 \\
Maximum increase $^{*}$ & $\%$ & 8.6 & 30.8 & 17.3 & 19.1 & 12.2 & 10.3 \\
Maximum decrease $^{*}$ & $\%$ & -8.0 & -13.9 & -11.8 & -13.1 & -10.0 & -19.5 \\
\hline
\end{tabular}

${ }^{*}$ Maximum increase/decrease in prices between two consecutive quarters.

In Germany, the minimum price was almost equal to the maximum price in Poland $\left(57.8 \mathrm{~m}^{-3}\right)$. The largest price variability was found in the Slovak, Polish, and Czech markets, while Austria and Slovenia exhibited the lowest variability. The greatest price increase between two consecutive quarters was recorded in the Czech market $(+30.8 \%)$, and the greatest decrease in the Polish market $(-19.5 \%)$.

\subsection{Seasonal, Cyclical, and Irregular Price Components}

The decomposition of quarterly time series of beech roundwood prices revealed seasonal, cyclical, and irregular components in the analyzed markets (Figures 5-7).
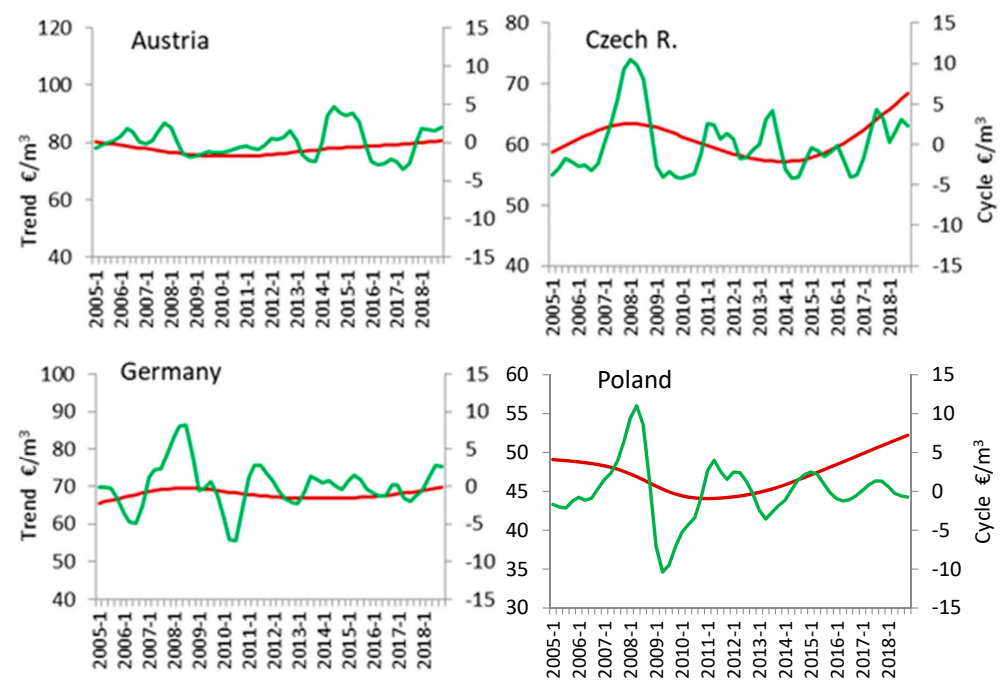

Figure 5. Cont. 


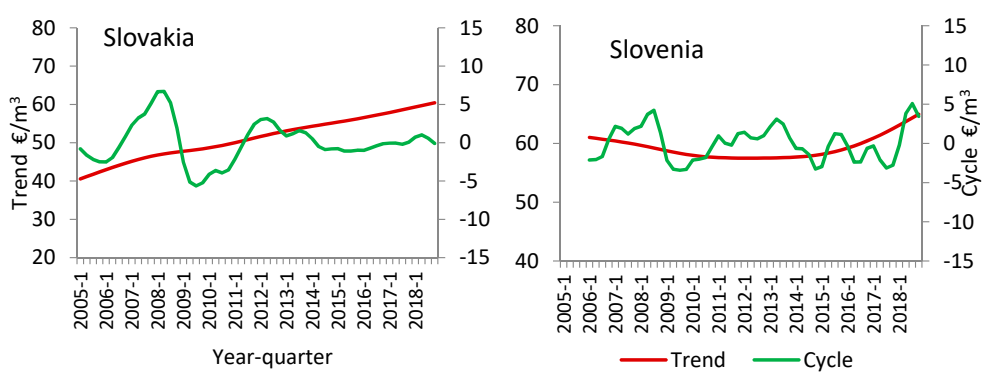

Figure 5. Long-term trend and cyclical fluctuations of beech roundwood prices in selected European countries in 2005-2018. Cyclical fluctuations (left axis) are expressed in $€ \mathrm{~m}^{-3}$ as positive and negative deviations from the long-term trend at a given time point.
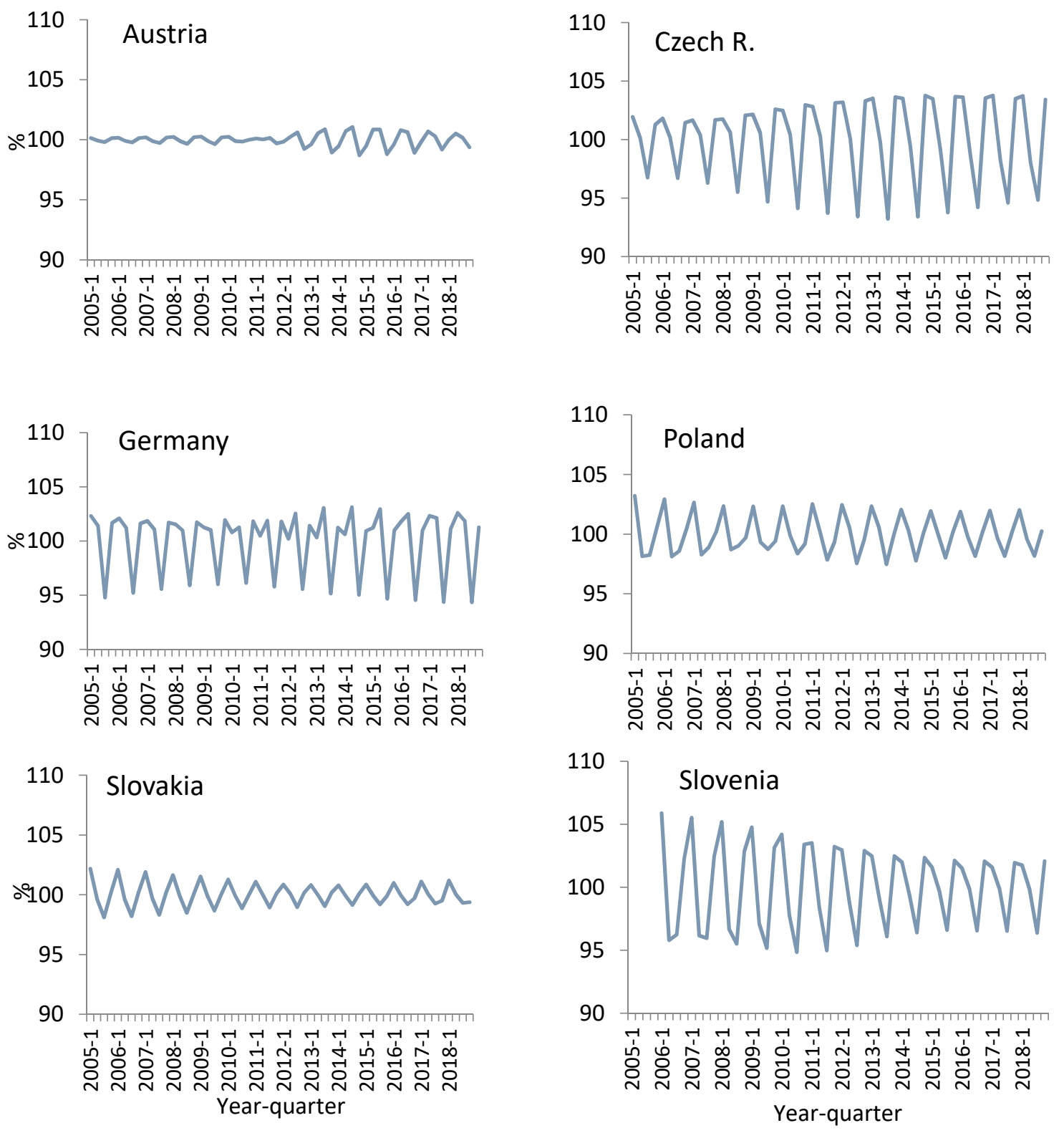

Figure 6. Seasonal fluctuations of beech roundwood prices in selected European countries in 2005-2018. 

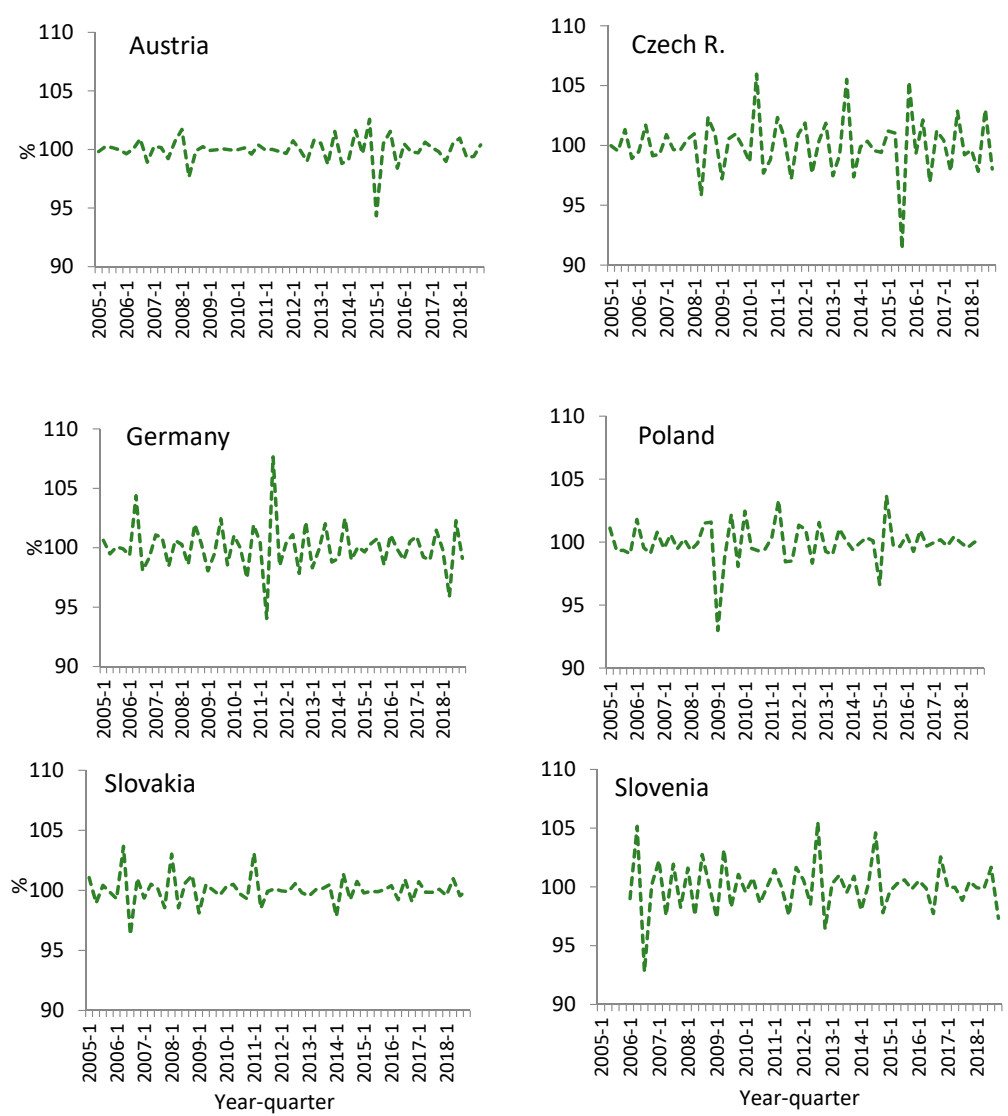

Figure 7. Irregular changes in beech roundwood prices in selected European countries in 2005-2018.

In Austria, beech roundwood prices were much higher than the mean price in the Central European market. Prices fluctuated around a stable level without a clear long-term trend, with small amplitudes of cyclical variability. The largest amplitude of irregular changes $(8.2 \%)$ was found in Q1 2015. The seasonal component did not reach statistical significance (Table 2).

Table 2. Statistical parameters of seasonal variability of beech roundwood prices in selected European countries in 2005-2018.

\begin{tabular}{|c|c|c|c|c|c|c|}
\hline Country & $F$ Test & $p$-Value & Year & Maximum *\% & Minimum * \% & Amplitude \% \\
\hline Austria & 0.51 & 0.68 & & & Not significant & \\
\hline \multirow{2}{*}{ Czechia } & \multirow{2}{*}{25.68} & \multirow{2}{*}{0.0001} & 2005 & 101.9 (Q1) & 96.7(Q3) & 5.2 \\
\hline & & & 2018 & 103.7 & 94.8 & 8.9 \\
\hline \multirow{2}{*}{ Germany } & \multirow{2}{*}{21.19} & \multirow{2}{*}{0.0001} & 2005 & 102.3 & 94.8 & 7.5 \\
\hline & & & 2018 & 102.6 & 94.3 & 8.3 \\
\hline \multirow{2}{*}{ Slovenia } & \multirow{2}{*}{20.30} & \multirow{2}{*}{0.0001} & 2006 & 105.9 & 95.8 & 10.1 \\
\hline & & & 2018 & 102.1 & 96.4 & 5.7 \\
\hline \multirow{2}{*}{ Poland } & \multirow{2}{*}{7.00} & \multirow{2}{*}{0.001} & 2005 & 103.2 & 98.1 & 5.1 \\
\hline & & & 2018 & 102 & 98.2 & 3.8 \\
\hline \multirow{2}{*}{ Slovakia } & \multirow{2}{*}{10.74} & \multirow{2}{*}{0.0001} & 2005 & 102.2 & 98.1 & 4.1 \\
\hline & & & 2018 & 101.2 & 99.3 & 1.9 \\
\hline
\end{tabular}

Max—always in Q1, Min—always in Q3, * Q3—third quarter of the year. 
The Czech market exhibited a mixed long-term trend: increasing to Q2 2008, followed by a gradual decline to Q1 2014, and then increasing again to 2018. Cyclical fluctuations were highly variable in terms of both cycle length and amplitude. In the analyzed period, the upper inflection points fell on Q1 2008, Q1 2011, and Q3 2013, and the lower inflection points on Q3 2010, Q3 2012, and Q2 2014. The largest seasonal amplitude was found between Q3 (93\%) and Q4 (104\%) both in 2013 and 2014. In general, the highest prices were observed in Q1, and the lowest in Q3. The amplitude of irregular changes mostly ranged between 1\% and 3\%, with a maximum of 14\% between Q3 and Q4 2015.

In Germany, the trend in beech roundwood prices was increasing to 2007, subsequently decreasing to 2011, and then again increasing since 2016. Cyclical fluctuations were highly variable both in terms of amplitude and cycle length, with two major cycles identified in 2006-2010 and 2010-2012 (in subsequent years amplitudes were low). The upper inflection points fell on Q2 2008 and Q3 2011, and the lower ones on Q2 2010 and Q3 2012. After 2012, the prices were more stable. The greatest irregular change was recorded between Q2 and Q3 2011 (20\%).

Up to 2010, the Polish market was characterized by a downward trend, followed by a period of stabilization, and an increasing trend between 2013 and 2018. Large-diameter beech log prices were sensitive to negative economic sentiment, giving rise to numerous cyclical changes, especially between 2007 and 2013. The largest irregular changes were found in Q1 $2009(-8 \%)$ and Q2 $2015(+7 \%)$. In terms of seasonal patterns, until the year 2010 roundwood prices were higher in Q1 and Q4 than in Q2 and Q3. While that pattern was not observed in subsequent years, Q3 prices continued to be the lowest (Table 2).

The Slovak market was characterized by a stable upward trend throughout the study period with decreasing amplitudes of cyclical and seasonal fluctuations. The years 2005-2008 saw roundwood price increase followed by a $14 € \mathrm{~m}^{-3}$ decline between Q1 2008 and Q3 2009. Since Q4 2009, the prices returned to a path of continuous growth. The largest amplitude of irregular fluctuations occurred between Q2 and Q3 2006.

In Slovenia beech roundwood prices exhibited irregular patterns, ranging from 51.21-68.02€ $\mathrm{m}^{-3}$. Cyclical fluctuations reflected slight deviations from the trend line, with seasonal amplitudes decreasing throughout the study period.

The effects of seasonal, cyclical, and irregular fluctuations on the overall price variation primarily depended on the adopted time span and greatly differed between the selected countries (Table 3). Within a one-quarter span, Czech, German, and Slovenian price series were dominated by seasonal fluctuations, which accounted for $54.1 \%, 60.2 \%$, and $54.9 \%$ of overall variation, respectively. In turn, cyclical variability was dominant in Poland and Slovakia, explaining $53.5 \%$ and $47.6 \%$ of the overall price variation, respectively. Finally, irregular changes were the predominant component of the Austrian price time series (49.2\%). Within a two-quarter span, cyclical price fluctuations dominated in Austria, Germany, Poland, and Slovakia, while seasonal variability was the component in Czechia $(51.6 \%)$ and Slovenia (67.5\%) (Table 3). In terms of annual average values, cyclical fluctuations explained the largest portion of price variation, while irregular changes accounted for the smallest percentage of price variation (from $7.6 \%$ in Poland to $23.5 \%$ in Austria).

Table 3. Relative contributions of irregular, cyclical, and seasonal components to the overall price variation depending on time span.

\begin{tabular}{ccccc}
\hline Country & Time Span in Quarters & Irregular Component & Cyclical Component & Seasonal Component \\
\hline \multirow{4}{*}{ Austria } & 1 & 49.2 & 39.5 & 11.3 \\
& 2 & 21.9 & 64.6 & 13.5 \\
& 3 & 9.3 & 86.5 & 4.2 \\
\hline \multirow{4}{*}{ Czechia } & Annual average & 23.5 & 69.2 & 7.3 \\
& 1 & 25.1 & 20.7 & 54.1 \\
& 2 & 11.5 & 36.9 & 51.6 \\
& 3 & 6.1 & 66.6 & 27.2 \\
\hline
\end{tabular}


Table 3. Cont.

\begin{tabular}{ccccc}
\hline Country & Time Span in Quarters & Irregular Component & Cyclical Component & Seasonal Component \\
\hline \multirow{5}{*}{ Germany } & 1 & 24.4 & 15.4 & 60.2 \\
& 2 & 15.2 & 43.6 & 41.1 \\
& 3 & 5.4 & 59.8 & 34.8 \\
& Annual average & 15.0 & 50.9 & 34.1 \\
\hline \multirow{5}{*}{ Poland } & 1 & 17.8 & 53.5 & 28.7 \\
& 2 & 5.8 & 76.8 & 17.5 \\
& 3 & 3.8 & 88.7 & 7.6 \\
\multirow{5}{*}{ Slovakia } & Annual average & 7.6 & 78.9 & 13.4 \\
& 1 & 31.7 & 47.6 & 20.7 \\
& 2 & 7.8 & 80.8 & 11.5 \\
\multirow{5}{*}{ Slovenia } & 3 & 4.9 & 90.2 & 4.9 \\
& Annual average & 12.1 & 78.6 & 9.3 \\
\hline
\end{tabular}

\subsection{Price Cointegration}

The time series of beech roundwood prices were tested for unit roots (non-stationarity), with the results provided in Table 4. Both KPSS and ADF indicated the stationarity of time series in Austria, Czechia, Germany, and Poland, and so they did not meet the qualifying condition for cointegration testing. In contrast, the price series for Slovakia and Slovenia exhibited first-order integration I(1), and so they could be tested for cointegration.

Table 4. KPSS stationarity and ADF non-stationarity tests for beech roundwood prices and the first differences of price time series.

\begin{tabular}{ccccc}
\hline Country & \multicolumn{2}{c}{ Price Series } & \multicolumn{2}{c}{ First Differences of Price Time Series } \\
\hline & KPSS & ADF & KPSS & ADF \\
\hline Austria & 0.283 & $-2.740^{*}$ & 0.134 & $-7.105^{* *}$ \\
Czech & 0.148 & $-3.048^{*}$ & 0.148 & $-2.999^{*}$ \\
Germany & 0.089 & $-4.240^{* *}$ & 0.064 & $-3.478^{* *}$ \\
Poland & 0.186 & $-3.128^{*}$ & 0.062 & $-3.048^{*}$ \\
Slovakia & $1.182^{* *}$ & -1.643 & 0.047 & $-6.664^{* *}$ \\
Slovenia & $0.354^{*}$ & -0.417 & 0.193 & $-8.463^{* *}$
\end{tabular}

* and ${ }^{* *}$ indicate null hypothesis rejection at the $5 \%$ and $1 \%$ probability levels, respectively; the null hypothesis assumed time series stationarity in KPSS and time series non-stationarity in ADF.

Johansen's method performed for the time series of beech roundwood prices in Slovenia and Slovakia indicated the absence of cointegration between those markets (Table 5). A null hypothesis assuming no cointegrating vector was accepted both in the $\lambda$-trace $(p=0.1106)$ and $\lambda$-max $(p=0.2134)$ tests.

Table 5. Johansen's test for cointegrating vectors between beech roundwood prices in Slovenia and Slovakia.

\begin{tabular}{cccccc}
\hline Hypothesis & Eigenvalue & $\boldsymbol{\lambda}$-Trace Test & $\boldsymbol{p}$-Value & $\boldsymbol{\lambda}$-Max Test & $\boldsymbol{p}$-Value * \\
\hline$r=0$ & 0.1726 & 13.116 & 0.1106 & 10.040 & 0.2135 \\
$r=1$ & 0.0564 & 3.0757 & 0.0795 & 3.0757 & 0.0795 \\
\hline
\end{tabular}

${ }^{*} p$-values indicate the lowest significance levels at which the null hypothesis can be rejected. 
Further cointegration analysis employed the Engle-Granger procedure. In the first step, the condition of non-stationary price series and stationary first increments of those series was met for only two of the six analyzed countries, i.e., Slovenia and Slovakia (Table 4). The parameters of the cointegrating equation estimated in the second step were statistically significant (Table 6). In the third step, the null hypothesis of the ADF test assuming no stationary residuals from the regression model was not rejected ( $\tau$ statistic $=-1043$, asymptotic $p$-value $=0.895)$. This implies that the residuals from the model were not a stationary process, indicating the absence of a cointegrating relationship between beech roundwood prices in the Slovenian and Slovak markets.

Table 6. Parameters of the regression model for Slovenian prices (dependent variable) being explained by Slovak prices (independent variable).

\begin{tabular}{ccccc}
\hline Variable & Coefficient & Standard Error & Student's $T$-Test & $p$-Value \\
\hline Constant & 46.861 & 4.001 & 11.71 & 0.0001 \\
\hline Slovakia & 0.242 & 0.077 & 3.13 & 0.0028 \\
\hline
\end{tabular}

Finally, ADF was used to test the residuals from the tests for unit roots. The high asymptotic $p$-value of 0.895 did not allow rejecting the null hypothesis about residual non-stationarity, which indicates that the examined relationship was spurious, and so there was no long-term price equilibrium between Slovenia and Slovakia. Testing the converse relationship between Slovakia and Slovenia according to the same Engle-Granger procedure (not shown) also revealed unit roots in the residuals, which means that they also represented a non-stationary process, implying the absence of a cointegrating relationship between Slovak and Slovenian prices.

In other countries with price series of type $I(0)$ simple correlation between stationary beech roundwood prices is positive and of value: $0.77,0.73,0.64$ between Czechia-Poland, Czechia-Austria, and Austria-Poland, respectively. Mentioned above correlation coefficients are statistically significant $(p<0.001)$, but value of improved $\mathrm{R}^{2}(0.58,0.53,0.40$ respectively) indicated that other factors play great importance to shape price level of analyzed countries. Correlation of prices in Germany is of the value of $0.23,0.30$, and 0.46 between Austria, Czechia, and Poland, respectively. A summary of estimations is provided in the Supplementary Material (Table S1).

\section{Discussion}

Timber trade and markets are at the center of interest of timber producers and the wood industry. The European and global markets are interconnected and influence each other [23,77]. Timber production, prices, and the related variables depend on competition as well as European and global policies in this area. Roundwood prices are rarely determined by production costs; they are typically shaped by the market, and so it is necessary to monitor them not only in individual markets, but also internationally, to develop optimum trade strategies $[29,78]$.

There are some obvious linkages between the timber market and the general economic situation reflected in macroeconomic indicators and business cycles [79,80]. In the years 2000-2005, the beech roundwood market in Europe was unstable, with price increases attributable to roundwood and sawtimber exports to Asia [81]. In particular, the study period was characterized by growing exports to China, especially of hardwood [61]. In the years 2005-2008, the Central European market revealed an upward trend in timber prices with beech roundwood prices peaking at the height of economic prosperity in 2007 and 2008. In Germany, Czechia, and Poland beech roundwood reached the maximum nominal prices in Q1 2008 at $77.54 € \mathrm{~m}^{-3}, 75.66 € \mathrm{~m}^{-3}$, and $57.75 € \mathrm{~m}^{-3}$, respectively. The 2008-2009 slump in timber prices caused by the American financial crisis destabilized the large-diameter log market [3,82-85] with beech roundwood prices entering a period of stagnation in most European countries $[78,86]$. Shrinking demand led to a downturn in the beech roundwood market in 2009-2013, especially due to lower activity in the construction and manufacturing industries. On the other hand, 
over the past decade there was an increasing emphasis on wood as a renewable energy resource [87], in accordance with European Union policies in particular European Commission 2009 Directive 2009/28/EC of energy from renewable sources. Also the rising prices of fossil fuels have provided a growth impulse for the prices of beech fuel wood. In turn, the decreasing demand for hardwood furniture undermined the prices of sawmill timber [84]. The contribution of cyclical fluctuations to the overall beech roundwood price variation was the highest in Poland and Slovakia, amounting to $78.9 \%$ and $78.6 \%$, respectively. These two markets were the most sensitive to economic developments, exhibiting the highest price amplitudes within cycles. In contrast, roundwood prices in Slovenia and Germany were the most resilient to economic shocks. According to Gejdos et al. [69] the prices of beech sawtimber are likely to increase in the near future, except for Austria. As new technologies enable the use of beech roundwood in wooden constructions, greater demand for this assortment seems to be a matter of time.

On an annual scale, seasonal effects were less pronounced than cyclical fluctuations. The price seasonality present in many timber markets and the wood industry is attributable to natural and organizational conditions [88]. However, seasonality was not found in all markets or in all years [31,32]. Time series decomposition revealed beech roundwood price seasonality throughout Central Europe except for Austria. The amplitudes of seasonal price fluctuations were the largest between Q1 (highest prices) and Q3 (lowest prices). Due to the biotic factors (insects, fungi) and abiotic factors (high temperatures) present in the summertime, hardwood is mostly harvested in the period of dormancy during late autumn and winter. The higher prices recorded in that period are associated with a better assortment structure as well as sales terms and policies. It has been reported that timber sales from October to December command higher prices than those from April to June [24,89]. Seasonality is also affected by organizational factors characteristic of individual companies, such as stock levels and the seasonality of production processes (e.g., periods of inactivity). On the other hand, in wintertime, the more difficult conditions of timber harvesting and lower storage capacity may be conducive to price increases [90].

Irregular factors exerted the greatest effects on the overall price variation within a one quarter time horizon, in particular in Austria (49.2\%) and Slovenia (32.3\%) due to hard-to-predict natural events. On an annual scale, irregular changes were also the most pronounced in Austria (23.5\%) and Slovenia (18.7\%), as well as Germany (15\%). Natural disasters (windthrows, droughts, hailstorms, systemic diseases) and other random events primarily affected spruce stands. The oversupply of softwood also impacted beech roundwood prices as unpredictable climatic events and the dieback of spruce stands made it necessary to postpone beech harvest.

Beech roundwood prices reached the highest values in Austria, which has a highly developed wood industry with a large production potential reflected in the high volumes of imported timber. Austrian demand for timber is associated with the energy sector ( $3 / 4$ of energy biomass in that country consists of wood products). Overall roundwood prices in Austria grew in the years 2004-2008, and after the 2009 slump they rebounded to a maximum of approx. $100 € \mathrm{~m}^{-3}$ in 2014. The high supply of spruce wood led to an approx. $2 \%$ decline in overall timber prices in 2015-2017. In 2016, both spruce and fir roundwood was more expensive than beech roundwood (approx. $89.95 € \mathrm{~m}^{-3} \mathrm{vs} .76 .47 € \mathrm{~m}^{-3}$ ). The Austrian market revealed the greatest price stability with the lowest price variation (3.8\%) and with maximum quarter-to-quarter changes being $+8.6 \%$ and $-8 \%$. Cyclical fluctuations associated with the phases of the economic cycle had the greatest effect (69.2\%) on the price time series, with seasonal variations not being statistically significant. It should be noted that the Austrian wood market is prioritized by state policies as the wood industry features prominently in governmental programs positioning Austria as a forest-focused country. Since Austria imports sizable amounts of roundwood (e.g., 9.7 million $\mathrm{m}^{3}$ in 2016, mostly from Czechia and Germany) [91], some governmental programs are designed to mobilize the availability of domestic timber supply by providing substantive, marketing, and financial support to private owners (approx. $80 \%$ of Austrian forests are privately owned), which is likely to exert a stabilizing effect on the roundwood market in Austria. 
In the analyzed period, the Czech market faced a general oversupply of timber, and especially salvaged spruce roundwood. The overall volume of timber harvested in Czechia increased gradually to $19,387,000 \mathrm{~m}^{3}$, including $502,000 \mathrm{~m}^{3}$ of hardwood in 2017 . In recent years, overall timber prices declined by approx. 20\% [92], in contrast to the prices of large-diameter beech logs, which were higher than those in Slovenia, Slovakia, and Poland, and exhibited an upward trend after 2014. In the study period, seasonal fluctuations revealed an increasing effect on roundwood prices, with 2009 amplitudes reaching approx. 10\%. The largest irregular change occurred in Q2-Q3 2015, when market prices dropped in response to the hurricane Niklas, with a similar situation in Austria.

The German monthly index of timber prices $(2010=100 \%)$ revealed much higher prices of beech roundwood as compared to, e.g., oak, pine, and spruce in the years 2004-2010. In January 2005, the beech price index reached $120.8 \%$, as compared to $73.3 \%$ for oak, $79.6 \%$ for pine, and $69.4 \%$ for spruce. In the years 2007-2008, class B beech logs sold for 75-150 $€ \mathrm{~m}^{-3}$ depending on diameter, while class $C$ logs sold for $60-80 € \mathrm{~m}^{-3}$. Since mid-2010 the price index of large-diameter beech logs was lower than that for oak, pine, and spruce logs, with January 2018 index values being $109.3 \%$ for beech, $126.6 \%$ for oak, $120.2 \%$ for pine, and $117.7 \%$ for spruce. Mid-2018 saw an overall decline in the prices of timber (and especially spruce logs), except for beech roundwood, which recorded an approx. $2.5 \%$ increase. This may be attributed to the fact that exporters purchasing timber of all quality classes must increasingly compete in the roundwood market with large German buyers.

The overall annual timber consumption in Germany amounts to approx. 132 million $\mathrm{m}^{3}$. It should be noted that the increasing share of hardwood stands poses a challenge to the German sawmill sector as most value added in the German wood industry is generated by softwood (77\% of domestic consumption). Hardwood species represent different technological requirements as compared to softwood, and hardwood products are not considered very competitive in the construction sector. While the applications of beech roundwood are becoming increasingly diverse $[84,93,94]$ beech timber is mostly used as fuel and pulp, with sawmills processing only high quality assortments [95]. The development of innovative and commercially viable beech roundwood products is a technological challenge that could ensure greater profitability for the German timber industry.

A major problem with beech roundwood is its low general quality. In Poland, depending on the region, as much as $45-69 \%$ of large-diameter beech logs belong to the lowest timber class (WD) $[86,96,97]$. In North Rhine-Westphalia, red heartwood formation in beech trees has generated losses of approx. $€ 5.1$ million $[81,98]$. Thus, research into the determinants of wood quality may improve the economic efficiency of beech stands in particular, and the forest industry in general [6,93,99-101].

In the study period, overall timber prices in Poland followed a steady increasing trend. On the other hand, nominal beech roundwood prices revealed strong cyclicality without a clear trend from $49.27 € / \mathrm{m}^{3}$ in Q1 2005 to $51.63 € / \mathrm{m}^{3}$ in Q4 2018. Large-diameter beech log sales came under major economic pressures in the global markets, as reflected in the largest irregular and cyclical amplitudes among the analyzed markets. In 2005-2012, the supply of beech timber increased, and fluctuated around a level of approx. 1,000,000 $\mathrm{m}^{3} /$ year since 2013, with a $41-43 \%$ share of large-diameter logs [102].

The Slovak market was characterized by the highest variability of beech roundwood prices in the study period (12.2\%). Up to 2009, Slovakia had the lowest beech roundwood prices in Central Europe, which ranged from $39 € \mathrm{~m}^{-3}$ in Q2-Q3 2005 to $56 € \mathrm{~m}^{-3}$ in Q1 2008. That situation changed in 2009, when Slovakia joined the Euro zone, which eliminated the currency risk of exporters (since 2009, the lowest beech roundwood prices were found in Poland, approx. 10-20\% lower than in Slovakia). It should be noted that the adoption of the Euro by Slovakia led to an approx. 3.5-4\% increase in timber prices [103]. Slovakia is an open economy, and its development depends on demand in international markets. The financial results of Slovak forestry were negatively affected by the declining average timber prices since 2012. In 2016 timber sold for $46.74 € \mathrm{~m}^{-3}$, which means a $1.6 € \mathrm{~m}^{-3}$ decrease on 2012. Nominal beech roundwood prices exhibited an upward trend from Q3 2009 to Q4 2018. Beech roundwood supply in Slovakia is likely to increase due to the rising stocks of hardwood species, which reached 278.7 million $\mathrm{m}^{3}$ in 2017 (a 19.1\% increase on 2006). However, the declining popularity 
of beech roundwood products is problematic. In addition, the Slovak wood industry faces some serious challenges, such as the closure of all facilities processing beech roundwood [104]. The market is distorted by 10-year contracts offered by the State Forests (favoring exporters), which was reflected in the decreasing amplitudes of seasonal fluctuations. Currently, as much as $25 \%$ of roundwood is exported in unprocessed form, mostly to the EU market, which points to high price competitiveness.

In Slovenia the beech roundwood market was relatively stable. In 2014, softwood supply greatly increased due to salvage logging in the aftermath of natural disasters, which resulted in reduced hardwood harvesting. That situation led to an upward trend in beech roundwood prices since 2015 . Strong demand for beech and oak logs was also found in the neighboring countries of Italy and Austria, as Croatia restricted its beech roundwood exports. In the years 2012-2016, roundwood exports from Slovenia rose from 1.3 million $\mathrm{m}^{3}$ to approx. 3 million $\mathrm{m}^{3}$. Dedicated measures were implemented to support producers and the wood industry, encourage the development of linkages between companies, promote timber use, and create green jobs. The value added generated by the wood industry was also stimulated by government programs, such as the commercially profitable program of beech element production [105].

The conducted analyses revealed integration between the prices of large-diameter beech logs in Czechia, Austria, and Poland. Central European countries, which may be attributable to the relatively small size of the beech roundwood market as compared to the leading spruce and pine timber markets. Thus, Central Europe has partly integrated beech roundwood markets despite considerable exports and imports between them. It should be mentioned that time series of price are rather short for long time cointegration analysis, might prevent proper detection of cointegration. Wood markets tend to be more cointegrated within the borders of countries or regions, or between regions that share a common border $[106,107]$. Based on the cointegration results, it seems that with respect to beech roundwood a rather long-run relationship between Czechia, Poland, and Austria. The degree of market integration may also inform on timber trade flows and suitable responses to changing market conditions. The market is shaped by foreign trade, exports from Germany to Asia and from Slovakia to EU countries.

Numerous studies deploying a variety of research tools explored the horizontal cointegration of roundwood markets, both in Europe and the USA. Many authors have reported long-term relationships between prices. Olms and Siry [41] identified cointegration between the German and Norwegian softwood markets. Jukany and Lundmark [108] analyzed the cointegration of Scots pine and Norway spruce sales for three regions of Sweden in the years 1999-2012, indicating the existence of a uniform market. Nonetheless, other studies have not detected cointegration between neighboring markets or have reported mixed results. Long-term relationships were identified between the spruce-but not birch-markets of Estonia and Lithuania and between Finland and Latvia [109]. In turn, most softwood markets in the Baltic See region have not been found to be integrated [37].

\section{Conclusions}

In the years 2005-2018, beech roundwood prices were greatly varied in the studied Central European markets. The 2008/2009 financial crisis destabilized beech roundwood prices, with declines ranging from approx. $8 \%$ in Austria to $41 \%$ in Poland relative to the maximum values at the height of economic prosperity; the average decrease for Central Europe amounted to approx. $27 \%$ in nominal terms. The end of stagnation in the Central European roundwood market was reflected in substantial price increases beginning in 2014, except for Slovakia, where prices started to rise much earlier due to the adoption of the Euro. The 2018 nominal prices in Germany, Czechia, and Poland did not reach the values from before the economic crisis. In Austria and Slovenia, the Q1 2008 levels were exceeded in 2018 by $2.23 € \mathrm{~m}^{-3}$ and $1.85 € \mathrm{~m}^{-3}$, respectively.

Central European markets revealed pronounced seasonal fluctuations of large-diameter beech $\log$ prices, with the highest values typically observed in Q1 and the lowest in Q3. The amplitude of seasonal price variation was the largest in Slovenia in 2005 (10.1\%), while in Czechia and Germany 
seasonality effects increased throughout the study period. The lowest significant seasonal effects were observed in Slovakia, and in Austria seasonality did not reach statistical significance. Irregular or random factors had the lowest overall impact on prices. They were most noticeable within the shortest time span (one quarter), with the strongest effects in Austria (49.2\%), Slovenia (32.3\%), and Slovakia $(31.7 \%)$, and the weakest effects in the Polish market (17.8\%), which was the least affected by natural disasters. In an annual time horizon, the contribution of the irregular component ranged from $23.5 \%$ in Austria to $7.6 \%$ in Poland.

The relative effects of the seasonal, cyclical, and irregular factors on overall price variation primarily depended on the time horizon and greatly varied between countries. Within an annual time horizon, the largest effects were exerted by the cyclical component, especially in Poland (78.9\%), Slovakia (78.6\%), and Austria (69.2\%). Seasonal fluctuations were the largest in Slovenia (40.6\%), Germany (34.1\%), and Czechia (33.3\%). On an annual scale, the average effects of irregular changes were the lowest, ranging from $7.6 \%$ in Poland to 23.5 in Austria.

In countries with price series of type $I(0)$ simple correlation between stationary beech roundwood prices is positive and the strongest between Czechia-Poland and Czechia-Austria; on the other hand they are the weakest in the German market. In Slovakia and Slovenia with nonstationary price series, both Johansen's and Engle-Granger's tests for the cointegration of price time series revealed the absence of a long-term equilibrium between the analyzed beech roundwood markets.

Results revealed integration between the prices of large-diameter beech logs in Czechia, Austria, and Poland. It should be mentioned that in this study the time series of price used are rather short for long time cointegration analysis, which might prevent proper detection of cointegration between all analyzed countries.

Supplementary Materials: The following are available online at http://www.mdpi.com/1999-4907/11/9/902/s1, Table S1: Linear regression parameters of beech log timber price between countries (pairwise) with stationary price series.

Author Contributions: Conceptualization, A.K. and J.B.; Methodology, J.B. and A.K.; Software, J.B. and A.K.; Validation, A.K. and J.B.; Investigation, A.K. and J.B.; Writing-Oryginal draft preparation, A.K. and J.B.; Writing-Review and editing, A.K. and J.B.; Vizualization J.B.; Supervision, A.K. and J.B. All authors have read and agreed to the published version of the manuscript.

Funding: This study was financed by the Ministry of Science and Higher Education of the Republic of Poland.

Acknowledgments: The authors wishes to thank the anonymous reviewers for their comments, which greatly helped to improve the paper.

Conflicts of Interest: The authors declare no conflict of interest.

\section{References}

1. Hurmekoski, E.; Hetemäki, L. Studying the future of the forest sector: Review and implications for long-term outlook studies. For. Policy Econ. 2013, 34, 17-29. [CrossRef]

2. Gołos, P. Wartość zasobów leśnych Polski. Sylwan 2013, 1, 3-16.

3. Hlavackova, P.; Brezina, D.; Sujova, A. The price formation of raw wood in the czech republic and a comparison with the neighbor states. Proced. Econ. Financ. 2015, 26, 389-395. [CrossRef]

4. Kangas, J.; Leskinen, P.; Pukkala, T. Integrating timber price scenario modeling with tactical management planning of private forestry at forest holding level. Kangas Leskinen 2000, 34, 399-409. [CrossRef]

5. Alberdi, I.; Bender, S.; Riedel, T.; Avitable, V.; Boriaud, O.; Bosela, M.; Camia, A.; Cañellas, I.; Castro Rego, F.; Fischer, C.; et al. Assessing forest availability for wood supply in Europe. For. Policy Econ. 2020, 111, 102032. [CrossRef]

6. Knoke, T.; Stang, S.; Remler, N.; Seifert, T. Ranking the importance of quality variables for the price of high quality beech timber (Fagus sylvatica L.). Ann. For. Sci. 2006, 63, 399-413. [CrossRef]

7. Höwler, K.; Vor, T.; Seidel, D.; Annighöfer, P.; Ammer, C. Analyzing effects of intra-and interspecific competition on timber quality attributes of Fagus sylvatica L.-From quality assessments on standing trees to sawn boards. Eur. J. For. Res. 2019, 138, 327-343. [CrossRef] 
8. Vacek, Z.; Vacek, S.; Slanař, J.; Bílek, L.; Bulušek, D.; Štefančík, I.; Králíček, I.; Vančura, K. Adaption of Norway spruce and European beech forests under climate change: From resistance to close-to-nature silviculture. Cent. Eur. For. J. 2019, 65, 129-144. [CrossRef]

9. Nichols, J.D.; Bristow, M.; Vanclay, J.K. Mixed-species plantations: Prospects and challenges. For. Ecol. Manag. 2006, 233, 383-390. [CrossRef]

10. García-Robredo, F. Effect of species complementarity on financial return in mixed stands of european beech and scots pine in northern spain. Forests 2018, 9, 559. [CrossRef]

11. Knoke, T.; Ammer, C.; Stimm, B.; Mosandl, R. Admixing broadleaved to coniferous tree species: Areviewon yield, ecological stability and economics. Eur. J. For. Res. 2008, 127, 89-101. [CrossRef]

12. Knoke, T.; Kindu, M.; Jarisch, I.; Gosling, E.; Friedrich, S.; Bödeker, K.; Paul, C. How considering multiple criteria, uncertainty scenarios and biological interactions may influence the optimal silvicultural strategy for a mixed forest. For. Policy Econ. 2020, 118, 102239. [CrossRef]

13. Knoke, T.; Stimm, B.; Ammer, C.; Moog, M. Mixed forests reconsidered: A forest economics contribution on an ecological concept. For. Ecol. Manag. 2005, 213, 102-116. [CrossRef]

14. Neuner, S.; Knoke, T. Economic consequences of altered survival of mixed or pure Norway spruce under a dryer and warmer climate. Clim. Chang. 2017, 140, 519-531. [CrossRef]

15. Friedrich, S.; Paul, C.; Brandl, S.; Biber, P.; Messerer, K.; Knoke, T. Economic impact of growth effects in mixed stands of Norway spruce and European beech-A simulation based study. For. Policy Econ. 2019, 104, 65-80. [CrossRef]

16. Paluch, J. Buk Zwyczajny. Wzrost i Produkcyjność, 1st ed.; PWRiL: Warszawa, Poland, 2012; ISBN 978830901083.

17. Leskinen, P.; Kangas, J. Modelling and simulation of timber prices for forest planning calculations. Scand. J. For. Res. 1998, 13, 469-476. [CrossRef]

18. Leskien, P.; Kangas, J. Modelling future timber price development by using expert judgments and time series analysis: Silva Fennica. Silva Fenn. 2001, 35, 93-102.

19. Khajuria, R.P.; Kant, S.; Laaksonen-Craig, S. Modeling of timber harvesting options using timber prices as a mean reverting process with stochastic trend. Can. J. For. Res. 2012, 42, 179-189. [CrossRef]

20. Gonzalez-Gomez, M.; Bergen, V. Berücksichtigung der Nichtstationarität von Zeitreihen bei empirischen Untersuchungen des deutschen Rohholzmarktes. Allg. Forst Jagdztg. Allg. F. U. J. Ztg. 2014, 186, $53-62$.

21. Kolo, H.; Tzanova, P. Forecasting the German forest products trade: A vector error correction model. JFE 2017, 26, 35-45. [CrossRef]

22. Zhou, M.; Buongiorno, J. Space-Time Modeling of Timber Prices. J. Agric. Resour. Econ. 2006, 31, 40-56.

23. Buongiorno, J.; Rougieux, P.; Barkaoui, A.; Zhu, S.; Harou, P. Potential impact of a Transatlantic trade and investment partnership on the global forest sector. JFE 2014, 20, 252-266. [CrossRef]

24. Michinaka, T.; Kuboyama, H.; Tamura, K.; Oka, H.; Yamamoto, N. Forecasting monthly prices of japanese logs. Forests 2016, 7, 94. [CrossRef]

25. Knauf, M. An analysis of wood market balance modeling in Germany. For. Policy Econ. 2015, 50, 319-326. [CrossRef]

26. Beljan, K. Economic Analysis of Even-Aged Silver Fir (Abies alba Mill.) Forest Management Thesis. Ph.D. Thesis, University of Zagreb, Zagreb, Croatia, 2015.

27. Suchodolski, P.; Idzik, M. Identyfikacja i ocena zmienności cen drewna w nadleśnictwie Płock. Wiadomości Stat. 2018, 11, 41-55.

28. Malaty, R.; Toppinen, A.; Viitanen, J. Modelling and forecasting Finnish pine sawlog stumpage prices using alternative time-series methods. Can. J. For. Res. 2007, 37, 178-187. [CrossRef]

29. Buongiorno, J. Global modelling to predict timber production and prices: The GFPM approach. Forestry 2015, 88, 291-303. [CrossRef]

30. Hetemaki, L.; Hanninen, R.; Toppinen, A. Short-Term Forecasting models for the finnish forest sector: Lumber exports and sawlog demand. For. Sci. 2004, 50, 461-472.

31. Yin, R. Forecasting short-term timber prices with univariate ARIMA Models. SJAF 1999, 23, 53-58. [CrossRef]

32. Mei, B.; Clutter, M.; Harris, T. Modeling and forecasting pine sawtimber stumpage prices in the US South by various time series models. Can. J. For. Res. 2010, 40, 1506-1516. [CrossRef]

33. Tzanova, P. Time series analysis for short-term forest sector market forecasting. Austrian J. For. Sci. 2017, $134,2005-2230$. 
34. Toppienen, A. Incorporating cointegration relations in a short-run model of the Finnish sawlog market. Can. J. For. Res. 1998, 28, 291-298. [CrossRef]

35. Meyer, J.; Von Cramon-Taubadel, S. Asymmetric Price Transmission: A Survey. J. Agric. Econ. 2004, 55, 581-611. [CrossRef]

36. Mäki-Hakola, M. Roundwood Price Development and Market Linkages in Central and Northern Europe; Pellervo Economic Research Institute Working Papers: Helsinki, Finland, 2004.

37. Mäki-Hakola, M. Cointegration of the Roundwood Markets around the Baltic Sea: An Empirical Analysis of Roundwood Markets in Finland, Estonia, Germany and Lithuania; Pellervo Economic Research Institute Working Papers: Helsinki, Finland, 2002.

38. Mutanen, A.; Toppinen, A. Price dynamics in the Russian-Finnish roundwood trade. Scand. J. For. Res. 2007, 22, 71-80. [CrossRef]

39. Niquidet, K.; Manley, B. Testing for nonlinear spatial integration in roundwood markets. For. Sci. 2011, 57, 301-308.

40. Ning, Z.; Sun, C. Vertical price transmission in timber and lumber markets. JFE 2014, 20, 17-32. [CrossRef]

41. Olmos, M.; Siry, J. The law of one price in global coniferous sawlog markets. Silva Fenn. 2018, 52, 1-19. [CrossRef]

42. Kallio, A. Analysing the Finnish pulpwood market under alternative hypotheses of competition. Can. J. For. Res. 2011, 31, 236-245. [CrossRef]

43. Sun, C.; Zhang, D. Assessing the financial performance of forestry related investment vehicles: Capital asset pricing model vs. arbitrage pricing theory. Am. J. Agric. Econ. 2001, 83, 617-628.

44. Bolkesjø, T.F. Projecting pulpwood prices under different assumptions on future capacities in the pulp and paper industry. Silva Fenn. 2005, 39, 103-116. [CrossRef]

45. Beljan, K.; Posavec, S.; Orsag, S.; Teslak, K. Simulation model for prediction of timber assortment price trends in Croatia-A case study of brinje forest office. Drona Ind. 2017, 68, 145-152. [CrossRef]

46. Parajuli, R.; Tanger, S.; Joshi, O.; Henderson, J. Modeling prices for sawtimber stumpage in the south-central United States. Forests 2016, 7, 148. [CrossRef]

47. Bolte, A.; Czajkowski, T.; Kompa, T. The north-eastern distribution range of European beech a review. Forestry 2007, 80, 413-429. [CrossRef]

48. Kantor, P.; Hurt, V. Production potential and ecological stability of mixed forest stands in uplands-V. A mixed spruce/beech stand on a nutrient-rich site of the Křtiny Training Forest Enterprise. J. For. Sci. 2003, 49, 502-514. [CrossRef]

49. Hurt, V.; Kantor, P. Production potential and ecological stability of mixed forest stands in uplands-VI. A beech/larch stand on a mesotrophic site of the Křtiny Training Forest Enterprise. J. For. Sci. 2007, 53, 170-184. [CrossRef]

50. Stefancik, I.; Stefancik, L. Effect of long-term tending on qualitative and quantitative production in mixed stands of spruce, fir and beech on Motyčky research plot. J. For. Sci. 2003, 49, 108-124. [CrossRef]

51. Parobeková, Z.; Pittner, J.; Kucbel, S.; Saniga, M.; Filípek, M.; Sedmáková, D.; Vencurik, J.; Jaloviar, P. Structural diversity in a mixed spruce-fir-beech old-growth forest remnant of the western carpathians. Forests 2018, 9, 379. [CrossRef]

52. Gutsch, M.; Lasch-Born, P.; Suckow, F.; Reyer, C.P.O. Evaluating the productivity of four main tree species in Germany under climate change with static reduced models. Ann. For. Sci. 2016, 73, 401-410. [CrossRef]

53. Paul, C.; Brandl, S.; Friedrich, S.; Falk, W.; Härtl, F.; Knoke, T. Climate change and mixed forests: How do altered survival probabilities impact economically desirable species proportions of Norway spruce and European beech? Ann. For. Sci. 2019, 76, 363. [CrossRef]

54. Bolte, A.; Hilbrig, L.; Grundmann, B.; Kampf, F.; Brunet, J.; Roloff, A. Climate change impacts on stand structure and competitive interactions in a southern Swedish spruce-Beech forest. Eur. J. For. Res. 2010, 129, 261-276. [CrossRef]

55. Bartkowicz, L.; Jaworski, A.; Pach, M. Przypuszczalne mechanizmy zmian jaworu i buka w bieszczadzkich drzewostanach o charakterze pierwotnym. Roczniki Bieszczadzkie. Rocz. Bieszcz. 2008, 16, 33-46.

56. Lebourgeois, F.; Bréda, N.; Ulrich, E.; Granier, A. Climate-tree-growth relationships of European beech (Fagus sylvatica L.) in the French Permanent Plot Network (RENECOFOR). Trees 2005, 19, 385-401. [CrossRef] 
57. Augustaitis, A.; Jasineviciene, D.; Girgzdiene, R.; Kliucius, A.; Marozas, V. Sensitivity of beech trees to global environmental changes at most north-eastern latitude of their occurrence in Europe. Sci. World J. 2012, 1-12. [CrossRef]

58. Stjepanović, S.; Matović, B.; Stojanović, D.; Lalić, B.; Levanič, T.; Orlović, S.; Gutalj, M. The impact of adverse weather and climate on the width of european beech (fagus sylvatica 1.) tree rings in Southeastern Europe. Atmosphere 2018, 9, 451. [CrossRef]

59. Almeida, I.; Rösch, C.; Saha, S. Comparison of ecosystem services from mixed and monospecific forests in southwest Germany: A survey on public perception. Forests 2018, 9, 627. [CrossRef]

60. European Organization of the Sawmill Industry. Annual Report of the European Sawmill Industry 2018/2019; EOS: Brussels, Belgium, 2019.

61. Yang, L.; Yin, Z.; Gan, J.; Wang, F. Asymmetric price transmission of hardwood lumber imported by china after imposition of the comprehensive commercial logging ban in all natural forests. Forests 2020, 11, 200. [CrossRef]

62. European Organization of the Sawmill Industry. Annual Report of the European Sawmill Industry 2017/2018; EOS: Brussels, Belgium, 2018.

63. UNECE/FAO Forestry and Timber Section. Forest Products Annual Market Review 2018-2019; United Nation Publikation: Geneva, Switzerland, 2019; ISBN 978-92-1-117218-8.

64. UNCE. Forest. Data and Statistics. Available online: http://www.unece.org/forests/output/prices.html (accessed on 2 January 2020).

65. Forest Portal o Lesoch Slovenska. Available online: https://www.forestportal.sk (accessed on 13 February 2020).

66. Czech National Bank. Exchange Rate of the Czech National Bank. Available online: https://www.cnb.cz/cs (accessed on 15 March 2020).

67. National Bank of Poland. Exchange Rate of the Polish National Bank. Available online: https://www.nbp.pl /home.aspx?c=/ascx/archa.ascx (accessed on 6 April 2020).

68. Malinen, J.; Kilpeläinen, H. Price systems for standing sales of industrial roudwood in Finland. Balt. For. 2013, 19, 307-315.

69. Gejdoš, M.; Lieskovský, M.; Giertliová, B.; Němec, M.; Danihelová, Z. Prices of raw-wood assortments in selected markets of central Europe and their development in the future. Bioresources 2019, 14, 2995-3011.

70. Shiskin, J.; Young, A.H.; Musgrave, J.C. The X-11 Variant of the Census Method II Seasonal Adjustment Program. Technical Paper 15; US Goverment Printing Office: Washington, DC, USA, 1967.

71. Dickey, D.A.; Fuller, W.A. Likelihood ratio statistics for autoregressive time series with a unit root. Econometrica 1981, 49, 1057-1072. [CrossRef]

72. Kwiatkowski, D.; Phillips, P.; Schmidt, P.; Shin, Y. Testing the null hypothesis of stationarity against the alternative of unit root. J. Econom. 1992, 54, 159-178. [CrossRef]

73. Johansen, S. Statistical analysis of cointegration vectors. J. Econ. Dyn. Control 1988, 12, 231-254. [CrossRef]

74. Johansen, S.; Juselius, K. Maximum likelihood estimation and inference on cointegration-With applications to the demand for money. Oxf. Bull. Econ. Stat. 1990, 52, 169-210. [CrossRef]

75. Engle, R.; Granger, C.W.J. Co-integration and error correction: Representation, estimation and testing. Econometrica 1987, 55, 251-276. [CrossRef]

76. Gnu Regression. Econometrics and Time-Series Library. Available online: http://gretl.sourceforge.net/ (accessed on 4 May 2020).

77. Toivonen, R.; Toppinen, A.; Tilli, T. Roundwood Price Co-Movement in Austria, Finland and Sweden; Pellervo Economic Research Institute Working Papers: Helsinki, Finland, 2000; ISBN 952-5299-16-3.

78. Suchomel, J.; Gejdos, M.; Ambrusova, L.; Sulek, R. Analysis of price changes of selected roundwood assortments in some Central Europe countries. J. For. Sci. 2012, 58, 483-491. [CrossRef]

79. Petersen, B.; Strongin, S. Why are some industries more cyclical than others? J. Bus. Econ. Stat. 1996, 14, 189-198.

80. Mehrotra, S.N.; Kant, S.; Majumdar, I. Industry cycles in the US softwood lumber industry: 1985 through 2010. For. Prod. J. 2014, 64, 116-125. [CrossRef]

81. Pöhler, E.; Klingner, R.; Künniger, T. Beech (Fagus sylvatica L.)-Technological properties, adhesion behaviour and colour stability with and without coatings of the red heartwood. Ann. For. Sci. 2006, 63, 129-137. [CrossRef] 
82. Prka, M.; Krpan, A. Impact of tending measures on assortment structure of fellings in central croatian beech stands. Acta Silv. Lign. Hung. 2010, 6, 171-182.

83. Parajuli, R.; Chang, S.J.; Hill, R.C. How effective is the United States-Canada softwood lumber agreement 2006? An econometric study. For. Sci. 2015, 61, 1041-1049. [CrossRef]

84. Poljanec, A.; Kadunc, A. Quality and timber value of european beech (Fagus sylvatica L.) trees in the Karavanke region. Croat. J. For. Eng. 2013, 34, 151-165.

85. Gejdoš, M.; Potkány, M. Prediction and analysis of Slovakian timber trade on global market conditions. Serb. J. Manag. 2017, 12, 281-289. [CrossRef]

86. Kożuch, A.; Banaś, J.; Zięba, S.; Adamowicz, K. Analysis of the supply and price of beech wood in southern Poland. Acta Sci. Pol. Silv. 2016, 15, 87-96. [CrossRef]

87. Hatemaki, L.; Muys, B.; Pelkonen, P.; Pettenella, D. Forest Bioenergy in Europe: Reassessment Needed; European Forest Institute: Joensuu, Finland, 2014.

88. Zwirglmaier, K. Seasonality of Prices-The Example of German Timber Prices. Technisce Universitat Munchen. 2010. Available online: http://www.gipecofor.org/doc/drupal/liens_article/evenements/2010/ZWIRGLMAIER _IUFRO_Paris_Mai2010.pdf (accessed on 4 April 2020).

89. Brown, R.N.; Kilgore, M.A.; Coggins, J.S.; Blinn, C.R. The impact of timber-sale tract, policy, and administrative characteristics on state stumpage prices: An econometric analysis. For. Policy Econ. 2012, 21, 71-80. [CrossRef]

90. Wear, D.N.; Prestemon, J.P.; Foster, M.O. US forest products in the global economy. J. For. 2016, 114, 483-493. [CrossRef]

91. Federal Minister for Sustainability and Tourism. Austrian Market Report 2018; Federal Minister for Sustainability and Tourism-Forestry and Sustainability: Vienna, Austria, 2018.

92. UN Economic Commission for Europe. Market Statement of the Czech Republik 2018; UN Economic Commission for Europe Committee on Forests and the Forest Industry Seventy-Sixth Session: Vancouver, BC, Canada, 2018.

93. Puriṇa, L.; Dreimanis, A.; Kārkliṇa, A.; Sisenis, L.; Adamovičs, A.; Puriňš, M. Financial assessment of Fagus sylvatica stands in Latvia. For. Wood Process. 2017, 1, 81-85.

94. Wühlisch, G.V.; Muhs, H.J. Current State of European Beech (Fagus sylvatica L.) Forests in Germany. In COST Action E 52 Genetic Resources of Beech in Europe-Current State; Johann Heinrich von Thünen-Institut: Braunschweig, Germany, 2011; ISBN 978-3-86576-076-0.

95. Breinig, L.; Brüchert, F.; Haas, A.; Sauter, U.H. Evaluation of European Beech (Fagus sylvatica L.) Roundwood for Improved Production of Strength-Graded Lamellas. In Projekt-Wood Wisdom-Net Project European Hardwoods for the Bulding Sector (EU Hardwoods); University of Freiburg: Freiburg, Germany, 2015; Available online: https://www.researchgate.net/publication/301548219 (accessed on 10 April 2020).

96. Biel, A. Baza Surowcowa Buka Zwyczajnego (Fagus Sylvatica) i Jodty Pospolitej (Abies alba Mill.) w Bieszczadach Zachodnich; Manuskrypt SGGW: Warszawa, Poland, 2007.

97. Kaczmarski, W. Jakość Drewna Bukowego Pozyskiwanego w Nadleśnictwie Lutowiska; Manuskrypt SGGW: Warszawa, Poland, 2007.

98. Knoke, T. Value of Complete Information on Red Heartwood Formation in Beech (Fagus sylvatica). Silva Fenn. 2002, 36, 841-851. [CrossRef]

99. Deckmyn, G.; Mali, B.; Kraigher, H.; Torelli, N.; op de Beeck, M.; Ceulemans, R. Using the process-based stand model ANAFORE including Bayesian optimisation to predict wood quality and quantity and their uncertainty in Slovenian beech. Silva Fenn. 2009, 43, 523-534. [CrossRef]

100. Merganič, J.; Merganičová, K.; Marušák, R.; Tipmann, L.; Šálek, L.; Dragoun, L.; Stolariková, R. Relation between forest stand diversity and anticipated log quality in managed Central European forests. Int. J. Biodivers. Sci. Ecosyst. Serv. Manag. 2016, 12, 128-138. [CrossRef]

101. Russo, D.; Marziliano, P.A.; Macrì, G.; Zimbalatti, G.; Tognetti, R.; Lombardi, F. Tree growth and wood quality in pure vs. mixed-species stands of european beech and calabrian pine in mediterranean mountain forests. Forests 2020, 11, 6. [CrossRef]

102. Banaś, J.; Kożuch, A. The application of time series decomposition for the identification and analysis of fluctuations in timber supply and price: A case study from poland. Forests 2019, 10, 990. [CrossRef]

103. Antonoaie, V. The effects of the Euro adoption on the timber market in Romania. Bull. Transilv. Univ. Braşov 2013, 5, 29-36.

104. Gejdoš, M.; Danihelová, Z. Valuation and Timber Market in the Slovak Republic. Proced. Econ. Financ. 2015, 34, 697-703. [CrossRef] 
105. Slovenski Državni Gozdovi D.O.O. Letno Porocilo Skupine Slovenski Drzavni Gozdovi 2017; SiDG: Ljubliana, Slovenia, 2018.

106. Toppinen, A.; Toivonen, R. Roundwood market integration in Finland: A multi-variate cointegration analysis. J. For. Econ. 1998, 4, 241-265.

107. Chudy, R.P.; Hagler, R.W. Dynamics of global roundwood prices-Cointegration analysis. For. Policy Econ. 2020, 115, 102155. [CrossRef]

108. Jukany, V.C.; Lundmark, R. Dynamics of spruce and pine market integration in Sweden. Forests 2015, 6, 4617-4633.

109. Toppinen, A.; Vitanen, J.; Laskien, P.; Toivonen, R. Dynamic of roundwood prices in Estonia, Finland and Lithuania. Balt. For. 2005, 11, 88-96.

(C) 2020 by the authors. Licensee MDPI, Basel, Switzerland. This article is an open access article distributed under the terms and conditions of the Creative Commons Attribution (CC BY) license (http://creativecommons.org/licenses/by/4.0/). 